\title{
Prevalence of parasitic ova/cysts on fruits and vegetables sold in Afikpo North Local Government Area, Ebonyi State, Nigeria
}

\author{
Ngele, K. K. ${ }^{*}$, Ali Amos $\mathrm{Ndu}^{2}$, Aligwe Esther Nnenna ${ }^{2}$, Ujaa Mercy Ekemma ${ }^{2}$ and Ujum \\ Comfort Ikori ${ }^{2}$
}

${ }^{1}$ Biology/Microbiology/Biotechnology Department, Federal University Ndufu Alike Ikwo, Ebonyi State, Nigeria.

${ }^{2}$ Science Laboratory Technology Department, Akanu Ibiam Federal Polytechnic Unwana Ebonyi State, Nigeria.

*Corresponding author. Email: kayong73@gmail.com, kayong73@yahoo.com. Tel: +2348066316115.

Copyright @ 2017 Ngele et al. This article remains permanently open access under the terms of the Creative Commons Attribution License 4.0, which permits unrestricted use, distribution, and reproduction in any medium, provided the original work is properly cited.

Received 4th October, 2017; Accepted 31st October, 2017

\begin{abstract}
Fruits and vegetables are good sources of vitamin C, carotene, mineral elements, iron and fiber. Most fruits and vegetables are eaten raw without being cooked. This attitude has led to the development of some parasitic diseases caused by the ova/cysts of intestinal parasites. These parasitic diseases affect the normal health conditions of the body and its development. Hence the need to investigate the prevalence of ova/cysts on fruits and vegetables sold in Afikpo North Local Government Area, Ebonyi State, Nigeria. Out of 2,800 fruits sampled, $28.36 \%$ were contaminated with different species of ova/cysts of intestinal parasites. Of the fruits sampled, mango (Magnifera indica) was the most contaminated (35.75\%), while the least fruits contaminated were apple (Mallus domestica) $(22.25 \%)$ and water melon (Citrus vulgaris) $(22.25 \%)$. Also, of the 2,240 vegetables sampled, $44.87 \%$ were contaminated with various species of ova/cysts of intestinal parasites. Water leaf (Talinum triangulare) was the most contaminated $(50.00 \%)$, while okro (Abelmosecus esculentum) was the least contaminated (38.13\%). Fruits sampled from Enohia market were the most contaminated with ova/cysts of intestinal parasites (29.25\%) while fruits sampled from Eke market Afikpo were the least contaminated (18.50\%). Also, vegetables sampled from Akpoha market were the most contaminated with ova/cysts of intestinal parasites (45.00\%), while vegetables from Eke market Afikpo were the least contaminated (31.56\%). Of all the parasitic ova/cysts of intestinal parasites recovered, Ascaris lumbricoides was the most common in both fruits and vegetables sampled $(6.54 \%)$ and $(9.95 \%)$ respectively. While Balantidium coli was the least common in both fruits and vegetables sampled $(3.75 \%)$ and $(5.45 \%)$ respectively. Poor handling of fruits and vegetables were the major reasons for the high rate of contamination of fruits and vegetables in the study area. Building of shopping malls and proper washing of the fruits and vegetables are some safe practices that will help to checkmate the high incidence rate of contamination with parasitic ova/cysts.
\end{abstract}

Key words: Afikpo, fruits, intestinal parasites, ova/cysts, vegetables.

\section{INTRODUCTION}

Fruits and vegetables are of great importance in human health and development for normal balanced diet. They are important and must be included in our daily diets. Fruits and vegetables such as water leaf, lettuce, water melon, and cucumber have high water contents (Akprikian et al., 2003). Vegetables and fruits are good sources of vitamin C, carotene, mineral elements iron and fiber (Akprikian et al., 2003).
Regular consumption of fruits is associated with reduced risks of cancer, cardiovascular diseases such as coronary heart disease, stroke, cataracts and some of the functional declines associated with ageing (CDC, 2010). Diets that include a sufficient amount of potassium from fruits and vegetables also help to reduce the chances of developing kidney stones and the effect of bone loss (Simon-Oke et al., 2014). 
Fruits are good sources of fibers and carbohydrates. Some fruits have high caloric values and glycemic index and should be taken in moderation (Center for Disease Control, 2010). Fruits such as carrots, tomatoes, oranges, garden eggs are good antioxidants, neutralizes free radicals which are harmful molecules that damage the body cells and cause inflammation. They are commonly measured as oxygen radical absorbance capacity (ORAC) (Akprikian et al., 2003; Simon-Oke et al., 2014)

The nutritional values of vegetables vary. Vegetables have low protein and fat contents. They contain varying proportions of vitamins such as vitamin $\mathrm{A}, \mathrm{K}, \mathrm{B} 6, \mathrm{C}$ and D. Vegetables (such as fluted pumpkin, Amaranthus spp., water leaf) also contain phytochemicals which act as antioxidants, antibacterial, and have anti-viral and anticarcinogenic properties (Olrandi et al., 2002; Gruda, 2005)

Parasites may be transmitted from animals to humans, from humans to humans, food to humans or even humans to animals. Several parasites have emerged as significant cause of food borne and water borne diseases in the world. This is achieved through the consumption of contaminated food, and water or by eating raw fruits and vegetables that are contaminated with parasites ova or cysts (Cheesbrough, 2003).

Parasitic ova include ova of Ascaris lumbricoides, Trichuris trichuria, Ancyclostoma duodanale, and cysts include cysts of Balantidium coli, Entamoeba histolytica, Giardia intestinalis (Oliveirra and Germano, 199; WHO, 2003; Anh et al., 2007).

Fruits and vegetables can become contaminated while growing in the fields or during harvesting, handling processes, distribution and use (Beuchat, 19995; Nicholas and Smith, 2002). They are most times consumed raw. Consumption of such contaminated fruits and vegetables are considered as risk factors for the transmission of parasitic ova/cysts in humans (Cheesbrough, 2003).

In Africa, Nigeria precisely, the use of human feces and animal dung in enriching the soil for cultivation of crops mainly fruits and vegetables are on the increase. This medium helps in the transmission of parasitic ova/cysts causing several parasitic diseases (Lucas et al., 2000).

The peasant farmers in Nigeria who are mainly in charge of the cultivation of fruits and vegetables depend on irrigation when there is no rainfall for the cultivation of their crops all year round. Many of them use untreated human feces and animal dung as manure, which contain various species of cysts/ova of intestinal parasites that are of medical and veterinary importance (Okonkwo, 1998; Lucas et al., 2000).

However, the climate, vegetation and topography of Afikpo North Local Government Area in Ebonyi State, Nigeria are suitable for the cultivation of fruits and vegetables using rain during wet season and irrigation during dry season. It is a known fact that the use of untreated feces/animal dung, polluted irrigation water, are of great health risk to farmers and consumers of such crops produced with the contaminated irrigation water (Lucas et al., 2000; Cheesbrough, 2003). Raw waste water mostly contains high number of eggs (ova) and cysts of parasitic origin.

Thus, this study was aimed at investigating the parasitic ova/cysts on fruits and vegetables sold in Afikpo North Local Government Area, Ebonyi State, Nigeria.

\section{MATERIALS AND METHODS}

\section{Background of the study area}

The study was carried out in Afikpo North Local Government Area, Ebonyi State, Nigeria. Afikpo is located between latitudes $5^{\circ} 4^{\prime}$ and $6^{\circ} 3^{\prime} \mathrm{N}$ and longitudes $7^{\circ} 5^{\prime} \mathrm{E}$ and $7^{0} 55^{\prime} \mathrm{E}$. There are two main seasons in this area that is rainy season which is between April to October and dry season which lasts between November to March. The annual rainfall is about 160 to $220 \mathrm{~mm}$ with maximum precipitation occurring between July to September. The temperature ranges between 23.4 and $29.9^{\circ} \mathrm{C}$. The relative humidity is between 60 to $80 \%$ (National Population Census, 2006). Afikpo is bounded in the North by Ohaozara Local Government Area of Ebonyi State. By the East is Afikpo South Local Government Area, in the South by Cross River State and also in the West by Abia State (National Population Census, 2006). According to the 2006 National Population Census, the population of Afikpo is about 672,000 persons. The area is hilly with undulating plains. The people are predominantly farmers producing rice, cassava, yam, vegetables, palm oil and coco yam. They are also fishermen, hunters and a good number of them deal on timbers. They are hospitable and accommodating.

\section{Sample collection}

The study was carried out between October, 2014 and September, 2015. Seven different types of fruits which include garden eggs (Solanum aethiopium) (Anghara), apple (Mallus domestica), orange (Citrus sinensis) (Oroma), water melon (Citrullus vulgaris), banana (Musa aethiopium) (Ukom), paw paw (Carica papaya) (Mgbimgbi) and mango (Magnifera indica) (Maningo) were sampled from the study area. Also seven different types of vegetables, commonly consumed by the people, were sampled. The vegetables include; fluted pumpkin (Telfania occidental) (Ugu), water leave (Talinum triangulare) (Moimoi ikong), African salad Ukazi (Alfalfa spp.), okro (Abelmosecus esculentus) (Okwuru), African spinach (Amaranthus spinosus) (Inini ogwu), tomatoes (Lyperisicon esculentum) (Tumato) and pepper (Capsicum annuum) (Ose). Fifty fruits and forty bundles 
Table 1. Prevalence of parasitic ova on fruits and vegetables from different markets in Afikpo North Local Government Area.

\begin{tabular}{llll}
\hline Fruits/vegetables & No examined & No infected & \% prevalence \\
\hline Fruits & 2800 & 794 & 28.36 \\
Vegetables & 2240 & 1005 & 44.87 \\
Total & 5040 & 1799 & 35.69 \\
\hline
\end{tabular}

of vegetables were collected at random from each of the markets, making it a total of 2,800 fruits and 2,240 bundles of vegetables sampled. Eight different markets were sampled from Afikpo North Local Government Area. They include; Eke, Oziza, Akpoha, Kpogrikpo, Unwana, Enohia, Ibii and Amasiri markets.

\section{Parasitological examination of specimens}

The specimens were transported to the Science Laboratory Technology Department, Akanu Ibiam Federal Polytechnic Unwana for parasitological analysis. Sedimentation and floatation techniques were used in analyzing the samples (Cheesbrough, 2003).

\section{Floatation techniques}

The concentrated sodium chloride floatation technique was used for concentrating the cysts and ova of the parasites (2.1 gravity). Fruits and vegetables were weighed and washed in distilled water. The washings were centrifuged at $2500 \mathrm{rpm}$ for 5 minutes and the supernatant was decanted. Two $(2 \mathrm{~mL})$ of the sediment was placed in a $15 \mathrm{~mL}$ test tube which was filled with 2 $\mathrm{mL}$ concentrated sodium chloride solution to the brim. A cover slip was used to cover the test tube, and the preparation was allowed to stand for about 6 hours, giving enough time for the ova/cysts of the parasites to float on top of the test-tube and attach at the cover slip. The cover slip was placed face downwards on a slide and was viewed under $x 10$ and $x 40$ objectives with a drop of iodine under the cover slip for easy identification of the parasite (Cheesbrough, 2003; Arora and Arora, 2008).

\section{Sedimentation techniques}

About $25 \mathrm{~g}$ of the samples (fruits and vegetables) were weighed and washed in distilled water for the removal of parasitic ova/cysts. The suspension was strained through a sterile sieve to remove undesirable materials. The filtrate was centrifuged at $3000 \mathrm{rpm}$ for 15 minutes. The supernatant was discarded into a disinfectant container. The sediment was mixed up and a drop of it was placed on the centre of a clean grease free microscope slide and a clean cover slip was placed gently on the slide to avoid air bubbles. lodine was added through the cover slip into the preparation for easy identification of the parasite. The preparation was examined under the microscope for parasitic ova/cysts using $\mathrm{x} 10$ and $\mathrm{x} 40$ objectives (Cheesbrough, 2003; Damen et al., 2007; Arora and Arora 2008).

\section{Statistical analysis}

Chi square test was used in testing for the level of significance between the fruits and the vegetables.

\section{RESULTS}

Study on the parasitic ova/cysts of intestinal parasites contaminating fruits and vegetables sold in some selected markets in Afikpo North Local Government Area, Ebonyi State, Nigeria were carried out between October, 2014 and September, 2015. Out of 2,800 fruits sampled, $(28.36 \%)$ were contaminated with different species of ova/cysts of intestinal parasites. Also, of the 2,240 vegetables sampled, (44.87\%) were contaminated with various species of ova/cysts of intestinal parasites. The total prevalence of parasitic ova/cysts that contaminates the fruits and vegetables sampled was (35.69\%) (Table 1).

Table 2 shows the distribution of parasitic ova/cysts in relation to fruits sampled from the study area. Of the fruits sampled, mango (Magnifera indica) was the most contaminated (35.75\%), while the least fruits contaminated were apple (Mallus domestica) (22.25\%) and water melon (Citrus vulgaris) $(22.25 \%)$. Other fruits sampled include; garden egg (Solanum aethiopium) $(31.50 \%)$, orange (Citrus cinensis) (30.75\%), pawpaw (Carica papaya) $(30.00 \%)$ and banana (Musa acuminate) $(26.00 \%)$. The total prevalence of contamination was (28.36\%).

Table 3 also shows the distribution of ova/cysts of parasites recovered from vegetables. Water leaf (Talinum triangulare) was the most contaminated $(50.00 \%)$, while okro (Abelmosecus esculentum) was the least contaminated $(38.13 \%)$. Other vegetables sampled include; fluted pumpkin (Telfaria occidental (49.69\%), Alfalfa (Ukazi) (42.50\%), African spinach (Amaranthus spinosus) (46.25\%). Others were tomatoes (Lycoperisicon esculentum) (41.88\%) and pepper (Capsicum annuum) (45.63\%) (Table 3). Vegetables were more contaminated with ova/cysts of parasites than fruits $(p<0.05)$. 
Table 2. Distribution of parasitic ova/cysts on fruits sampled from Afikpo North Local Government Area.

\begin{tabular}{lccc}
\hline Fruits & No examined & No infected & \% prevalence \\
\hline Garden egg & 400 & 126 & 31.50 \\
Apple & 400 & 89 & 22.25 \\
Orange & 400 & 123 & 30.75 \\
Water melon & 400 & 89 & 22.25 \\
Pawpaw & 400 & 120 & 30.00 \\
Banana & 400 & 104 & 26.00 \\
Mango & 400 & 143 & 35.75 \\
Total & 2,800 & 794 & $28.36 \%$ \\
\hline
\end{tabular}

Table 3. Shows parasitic ova/cysts in relation to vegetables sampled from the markets in Afikpo North Local Government Area.

\begin{tabular}{lccc}
\hline Vegetables & No examined & No infected & \% prevalence \\
\hline Fluted pumpkin & 320 & 159 & 49.69 \\
Water leaf & 320 & 160 & 50.00 \\
Alfalfa (ukazi) & 320 & 136 & 42.50 \\
Okro & 320 & 122 & 38.13 \\
Amaranthus spinosus & 320 & 148 & 46.25 \\
Tomatoes & 320 & 134 & 41.88 \\
Pepper & 320 & 146 & 45.63 \\
Total & 2240 & 1005 & 44.87 \\
\hline
\end{tabular}

Table 4. Distribution of ova/cysts of intestinal parasites recovered from fruits in relation to markets sampled in Afikpo North Local Government Area.

\begin{tabular}{lcc}
\hline Markets $(\mathbf{n = 4 0 0 )}$ & No. infected & \% prevalence \\
\hline Eke & 74 & $(18.50)$ \\
Ozizza & 105 & $(26.25)$ \\
Akpoha & 113 & $(28.20)$ \\
Kpogirikpo & 98 & $(24.50)$ \\
Unwana & 81 & $(20.25)$ \\
Enohia & 119 & $(29.75)$ \\
Ibii & 100 & $(25.00)$ \\
Amasiri & 104 & $(26.00)$ \\
Total & 794 & $(28.36 \%)$ \\
\hline
\end{tabular}

Table 4 shows the distribution of ova/cysts of intestinal parasites recovered from the fruits in relation to markets sampled in Afikpo North Local Government Area. Fruits from Eke market were the least contaminated with intestinal parasites $(18.50 \%)$ while fruits from Enohia market were the most contaminated with ova/cysts of intestinal parasites (29.75\%).

The ova/cysts of intestinal parasites recovered from the vegetables sold in different markets in Afikpo North Local Government Area are shown in Table 5. Vegetables sampled from Eke market were the least contaminated with ova/cysts of intestinal parasites $(31.56 \%)$ while
Table 5. Distribution of ova/cysts of intestinal parasites recovered from vegetables in relation to markets sampled in Afikpo North Local Government Area.

\begin{tabular}{lcc}
\hline Markets ( $\mathbf{n = 3 2 0 )}$ & Number infected & \% Prevalence \\
\hline Eke & 101 & $(31.56)$ \\
Ozizza & 126 & $(39.38)$ \\
Akpoha & 144 & $(45.00)$ \\
Kpogirikpo & 136 & $(42.50)$ \\
Unwana & 113 & $(35.31)$ \\
Enohia & 140 & $(43.75)$ \\
lbii & 126 & $(39.38)$ \\
Amasiri & 119 & $(37.19)$ \\
Total & 1005 & $(44.87)$ \\
\hline
\end{tabular}

vegetables sampled from Akpoha market were the most contaminated (45.00\%).

Different species of ova/cysts of intestinal parasites recovered from fruits sampled in Afikpo North Local Government Area are shown in Table 6. Ascaris lumbricoides had the highest prevalence 183 (6.54\%) while Balantidium coli had the least prevalence $(3.75 \%)$ and a total prevalence of 105 (28.36\%).

Different species of ova/cysts of intestinal parasites recovered from vegetables sampled in Afikpo North Local Government Area are shown in Table 7. Ascaris lumbricoides had the highest prevalence 223 (9.95\%), 
Table 6. Different species of parasites ova/cysts recovered from fruits sampled and their percentage intensities $(n=2800)$.

\begin{tabular}{|c|c|c|c|c|c|c|c|c|c|c|c|c|c|c|}
\hline \multirow[t]{2}{*}{ Fruits } & \multicolumn{2}{|c|}{$\begin{array}{c}\text { Ascaris } \\
\text { umbricodes }\end{array}$} & \multicolumn{2}{|c|}{$\begin{array}{c}\text { Entamoeba } \\
\text { histolytica }\end{array}$} & \multicolumn{2}{|c|}{$\begin{array}{c}\text { Balanutidium } \\
\text { Coli }\end{array}$} & \multicolumn{2}{|c|}{ Giardia lamblia } & \multicolumn{2}{|c|}{ Hookworm ova } & \multicolumn{2}{|c|}{$\begin{array}{c}\text { Strongyloides } \\
\text { stercoralis }\end{array}$} & \multicolumn{2}{|c|}{ Total } \\
\hline & No. & $\%$ & No. & $\%$ & No. & $\%$ & No. & $\%$ & No. & $\%$ & No. & $\%$ & No. & $\%$ \\
\hline Garden egg & 31 & 1.11 & 18 & 0.64 & 14 & 0.50 & 20 & 0.71 & 22 & 0.79 & 21 & 0.75 & 126 & 4.50 \\
\hline Apple & 20 & 0.71 & 13 & 0.46 & 10 & 0.36 & 14 & 0.50 & 15 & 0.54 & 17 & 0.61 & 89 & 3.18 \\
\hline Orange & 29 & 1.04 & 20 & 0.71 & 18 & 0.64 & 17 & 0.61 & 20 & 0.71 & 19 & 0.68 & 123 & 4.39 \\
\hline Water melon & 19 & 0.68 & 15 & 0.54 & 12 & 0.43 & 13 & 0.46 & 16 & 0.57 & 14 & 0.50 & 89 & 3.18 \\
\hline Paw paw & 26 & 0.93 & 19 & 0.68 & 16 & 0.57 & 18 & 0.64 & 20 & 0.71 & 21 & 0.75 & 120 & 4.29 \\
\hline Banana & 22 & 0.79 & 15 & 0.54 & 14 & 0.50 & 19 & 0.68 & 16 & 0.57 & 18 & 0.64 & 104 & 3.71 \\
\hline Mango & 36 & 1.29 & 23 & 0.82 & 21 & 0.75 & 25 & 0.89 & 20 & 0.71 & 18 & 0.64 & 143 & 5.11 \\
\hline Total & 183 & (6.54) & 123 & (4.39) & 105 & (3.75) & 126 & (4.5) & 129 & (4.61) & 128 & $(4.57)$ & 794 & (28.36\%) \\
\hline
\end{tabular}

Table 7. Different species of parasites ova/cysts recovered from vegetables sampled and their percentage intensities $(n=2240)$

\begin{tabular}{|c|c|c|c|c|c|c|c|c|c|c|c|c|c|c|}
\hline \multirow[t]{2}{*}{ Vegetables } & \multicolumn{2}{|c|}{$\begin{array}{c}\text { Ascaris } \\
\text { umbricodes }\end{array}$} & \multicolumn{2}{|c|}{$\begin{array}{c}\text { Entamoeba } \\
\text { histolytica }\end{array}$} & \multicolumn{2}{|c|}{ Balanutidium Coli } & \multicolumn{2}{|c|}{ Giardia lamblia } & \multicolumn{2}{|c|}{ Hookworm ova } & \multicolumn{2}{|c|}{$\begin{array}{c}\text { Strongyloides } \\
\text { stercoralis }\end{array}$} & \multicolumn{2}{|c|}{ Total } \\
\hline & No. & $\%$ & No. & $\%$ & No. & $\%$ & No. & $\%$ & No. & $\%$ & No. & $\%$ & No. & $\%$ \\
\hline Fluted pumpkin & 32 & 1.43 & 26 & 1.16 & 22 & 0.98 & 28 & 1.25 & 27 & 1.21 & 24 & 1.07 & 159 & 7.09 \\
\hline Water leaf & 40 & 1.78 & 28 & 1.25 & 18 & 0.80 & 25 & 1.12 & 27 & 1.21 & 22 & 0.98 & 160 & 7.14 \\
\hline Alfalfa (ukazi) & 28 & 1.25 & 23 & 1.03 & 16 & 0.71 & 26 & 1.16 & 24 & 1.07 & 19 & 0.85 & 136 & 6.07 \\
\hline Okro & 26 & 1.16 & 20 & 0.89 & 13 & 0.58 & 21 & 0.94 & 23 & 1.03 & 19 & 0.85 & 122 & 5.45 \\
\hline African spinach & 33 & 1.47 & 23 & 1.03 & 19 & 0.85 & 25 & 1.12 & 26 & 1.16 & 22 & 0.98 & 148 & 6.61 \\
\hline Tomatoes & 29 & 1.29 & 20 & 0.89 & 16 & 0.71 & 24 & 1.07 & 27 & 1.21 & 18 & 0.80 & 134 & 5.98 \\
\hline Pepper & 35 & 1.56 & 22 & 0.98 & 18 & 0.80 & 27 & 1.21 & 24 & 1.07 & 20 & 0.89 & 146 & 6.52 \\
\hline Total & 223 & $(9.95)$ & 162 & $(7.23)$ & 122 & $(5.45)$ & 176 & $(7.8)$ & 178 & $(7.95)$ & 144 & (6.43) & 1005 & (44.87\%) \\
\hline
\end{tabular}

while Balantidium coli had the least prevalence $(5.45 \%)$. There is significant difference $(p<0.05)$ with regards to parasitic distribution on fruits and vegetables sampled.

\section{DISCUSSION}

Out of the 2,800 fruits sampled from eight markets in Afikpo North Local Government Area, (28.36\%) were contaminated with different species of ova/cysts of different intestinal parasites. Also, out of 2,240 vegetables sampled from eight markets selected at random, (44.87\%) were contaminated with different ova/cysts of intestinal parasites. Vegetables were more contaminated with parasitic ova/cysts than fruits $(44.87 \%)$ and $(28.36 \%)$ respectively. However, there is a level of significance between the vegetables and the fruits sampled $(p>0.05)$. The results of this study on the prevalence of parasitic ova/cysts on fruits and vegetables are supported by the works of Shahnazi and Jafari-sabet (2010) in Saudi Arabia and Hassan et al., (2012) in Egypt. The results of this study agreed with the findings of Leon (1992) and Damen et al., (2007) who carried out their research works in Manila, Philipines and Jos, Nigeria on fruits and vegetables respectively.

Of the vegetables sampled, water leaf was the most contaminated with ova/cysts of parasites. These findings are in line with the results of Ohaeri et al. (2011) and Dauda et al. (2011). This is because water leaf stem is short, and it does not grow tall. This predisposes it to contamination by parasitic ova/cysts during flooding, as well as heavy rain splashes from the soil. Mango was the most contaminated with ova/cysts of intestinal parasites. Mango usually has an odor that attracts flies that mostly carry the ova/cysts on its body 
and deposit it on mango while perching on it. In rural areas, people are fond of picking mango from the soil which is contaminated with different parasitic ova/cysts and eat without washing, but may wipe it with their bare dirty hands or cloths which are contaminated. This is a very common method of contacting ova/cysts of intestinal parasites (Cheesbrough, 2003; Al-shawa and Mwafy, 2007; Ngele, 2011; Ngele, 2012). Fruits sampled from Enohia market were the most contaminated (29.75\%) while fruits sampled from Eke market Afikpo were the least contaminated (18.50\%). Also vegetables sampled from Akpoha market were the most contaminated with cysts/ova of intestinal parasites $(45.00 \%)$, while vegetables sampled from Eke market Afikpo were the least contaminated $101(31.56 \%)$. The reason for the differences in the rates of contamination of fruits and vegetables from the markets sampled may be as a result of the sources of water used for irrigation and also the exposure of the items to open environment. That is, the poor filthy environment, coupled with heaps of refuse dumps within and around the markets contributed to the high rates contamination of ova/cysts of intestinal parasites on the fruits/vegetables as recorded in this study (Geruda, 2005; Simon-oke et al., 2014).

Ascaris lumbricoides was the commonest intestinal parasite recovered during the study, while the least intestinal parasite recovered was Balantidium coli. Other intestinal parasites recovered include; Entamoeba histolytica, Giardia lamblia, Hookworm ova, Strongyloides stercoralis. Shuval et al. (1984), Stephenson (1987), Ohaeri et al. (2011), Dauda et al. (2011), Simon-oke et al. (2014) also maintained that $A$. lumbricoides was the commonest intestinal parasite recovered from their different studies.

In conclusion, the research work has shown that fruits and vegetables sold in Afikpo North Local Government Area were contaminated with ova/cysts of intestinal parasites. Dirty environments and improper or poor handling of fruits and vegetables are some major causes of contamination with ova/cysts of intestinal parasites. It is therefore recommend that proper hygiene should be practiced in handling fruits and vegetables to avoid its contamination with parasitic ova/cysts of intestinal parasites. Also, Government should make it as a standing order by insisting that fruits and vegetables should be sold in enclosed shopping malls only, and no longer in open places to avoid its contamination. There should equally be public enlightenment and awareness campaign on the dangers associated with intestinal parasites.

\section{CONFLICT OF INTEREST}

The authors declare that they have no conflict of interest.

\section{REFERENCES}

Akprikian, O., Duclos, V., Besson, C., Manach, C., Benaliar, A., Morand, C., \& Remesy, C. (2003). Apple pectin and polyphenal-rich apple concentrate are more effective than separate local fermentations and plasma lipids in rats. Journal of Nutrition, 133 (6), 1860-1865.

Al-Shawa, R. M., \& Mwafy, S. N. (2007). The enteroparasic contamination of commercial vegetables in Gaza Governorates. J. Infect. Dev. Tries, 1, 62-66.

Arora, D. R., \& Arora, B. (2008). Medical Parasitology, $2^{\text {nd }}$ Edition, New Delhi India pp: 168-180.

Beuchat, C. R. (1995). Pathogenic micro-organism association with fresh produce. Journal of Food Protection, 59(6), 204.

Cheesbrough, M. (2003). District Laboratory practice in Tropical Countries part 1, Cambridge University press Cambridge. Pp. 206-207.

Damen, J. G., Banwat, E. B., Egah, D. Z., \& Allamana, J. A. (2007). Parasitic contamination of vegetables in Jos, Nigeria. Annal of African medicine, 6(2), 115-118.

Center for Disease control and Prevention (CDC) (2010). Epidemiological information, $4^{\text {th }}$ Edition, Atlanta, U.S.A. Pp. 50-55.

Dauda, M., Medinat, M., \& Sabiu, T. (2011). Parasitic contamination of fruits and vegetables sold at Kaduna metropolis, Nigeria. Nigerian Journal of Parasitology, 32(2), 309-314.

Geruda, N. (2005). Impact of Environmental factors on product quality of Greenhouse vegetables for fresh consumption. Macmilian publishers, Ibadan. Pp. 227-234.

Lucas, S., Ajugi, I., \& Umuh, J. (2000). Helminthosis among primary school children. Journal of Parasitology, 21, 109-116.

Leon, W. (1992). Parasitic contamination of fresh vegetables sold in metropolitan manila, Philipines, South East. Journal of Tropical Medicine and Public Health, 23(1), 162-164.

National Population Census (2006). http://population.gov.ng/.

Ngele, K. K. (2011). Prevalence of intestinal parasites among primary school pupils in Unwana primary schools 1 and 2 . African Journal of Sciences, 12(1), 2782-2794.

Ngele, K. K. (2012). The prevalence of intestinal protozoa parasites among the undergraduate students of Akanu Ibiam Federal Polytechnic Unwana, Ebonyi State, Nigeria. International Journal of Science and Nature, 3(4), 876-878.

Ohaeri, C., \& Unogu, L. (2011). Soil transmitted Helminthes of some common vegetables in Umuahia, Abia State, Nigeria. Nigerian Journal of Parasitology, 32(2), 305-308.

Okoronkwo, M. O. (1998). Intestinal parasites associated with human and animal waste stabilization in Jos and Barkin Raw Areas of Plateau State, Nigeria Ph.D Thesis, University of Jos, Jos.

Simon-Oke, I. A., Afolabi, O. J., \& Obasola, O. P. (2014). Parasitic contamination of fruits and vegetables sold at Akure Metropolis, Ondo State, Nigeria. Researcher, 6(12), 30-35.

Shahnazi, M. \& Jafari-Sabet, M. (2010). Prevalence of parasitic contamination of raw vegetables in villages of Qazvin Proinie, Iran. Foodborne Pathogen Dis., 7, 1025-1030.

Shuval, H. I., Yekutiel, P., \& Fattal, B. (1985). Epidemiological evidence for helminth and cholera transmission by vegetables irrigated with wastewater: Jerusalem-a case study. Water science and Technology, 17(4-5), 433-442.

Stephenson, L. S. (1987). Impact of helminthes infection on human nutrition. Taylor and Francis, New York. Pp. 252-260.

Anh, V. T., Tram, N. T., Klank, L. T., Cam, P. D., \& Dalsgaard, A. (2007). Faecal and protozoan parasite contamination of water spinach (Ipomoea aquatica) cultivated in urban wastewater in Phnom Penh, Cambodia. Tropical Medicine and International Health, 12(s2), 73-81.

World Health Organization (WHO) (2003). Bulletin of the World Health Organization Geneva. Pp. 17-23. 